\title{
THE ORIGIN OF THE OLD ENGLISH DIALECTS REVISITED
}

\author{
by Frederik Kortlandt — Leiden
}

Did the Old English dialects first diverge in Britain or on the Continent? In an earlier study (1986) I argued that neither view is correct and that the early divergences between West Saxon and Kentish on the one hand and Anglian on the other are the result of a chronological difference between two waves of migration from the same dialectal area in northern Germany. I argued that West Saxon has preserved two structural archaisms, viz. the nom.pl. ending of the $\bar{o}$-stems $-a$ and the reflex $\bar{\varpi}$ of PIE $* \bar{e}$, whereas Anglian has retained five accidental irregularities which are also found in Old Norse, Gothic or Old High German. Besides, Anglian differs from West Saxon as a result of seven innovations shared with continental West Germanic languages: the substitution of the acc.pl. ending of the o-stems $-e$ for the nom.pl. ending, the creation of a distinct accusative of the 1 st and 2 nd $\mathrm{sg}$. personal pronouns, the creation of the $1 \mathrm{st}$ pl. possessive pronoun $\bar{u} s a$, the introduction of e-vocalism in the acc.sg. form of the masc. demonstrative pronoun, the creation of 1st sg. beom 'am', the spread of

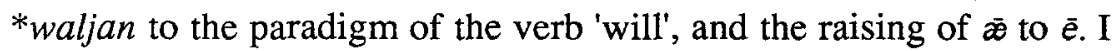
therefore distinguished between an earlier, "Saxon" invasion which resulted in the conquest of Kent and Sussex in the fifth century and a later, "Anglian" invasion which can be connected with the subjugation of the north starting around the middle of the sixth century. The shared innovations of Anglian and Old Saxon point to geographical contiguity after the early, "Saxon" migration.

Reconsidering the relative chronology of Anglo-Frisian sound changes, Robert Fulk arrives at the following conclusion for the Northumbrian dialect of Old English (1998: 153):

1. Backing and nasalization of West Gmc. a, à before a nasal consonant.

2. Loss of $n$ before a spirant, resulting in lengthening and nasalization of the preceding vowel. 
3. Fronting of West Gmc. $a, \bar{a}$ to $æ$, $\bar{x}$, including $a$ in the diphthongs $a i$ and $a u$.

4. Palatalization (but not yet phonemicization of palatals).

5. Retraction of $æ, \bar{x}$ to $a, \bar{a}$ due to the influence of neighbouring consonants.

6. Non-Saxon (and Frisian) $\not{x}>\bar{e}$.

7. Restoration of $a$ before a back vowel of the following syllable; at this time ( $a u$ was retracted to $a u$ in Old Frisian.

8. Breaking; in West Saxon, palatal diphthongization follows.

9. i-mutation, followed by syncope; Old Frisian breaking follows.

10. Phonemicization of palatals and assibilation, followed by second fronting in part of West Mercia.

11. Smoothing and back mutation.

In this chronology, English and Frisian begin to diverge at stage 5 and tend to diverge widely at stage 7 .

The main difficulty with Fulk's chronology is the unmotivated character of the sound changes: we find backing at stage 1, fronting at stage 3 , backing at stage 5 , fronting at stage 6 , backing at stage 7 , fronting at stage 9 , and backing at stage 11 . What was the driving force behind these alternating developments? Following Krupatkin's observation that "every time the initial shifts in the field of the long vowels raised similar transformations in the field of the short vowels" (1970: 63), we may look for structural pressure as a determinant factor. In my view, the basic element is the Proto-Germanic asymmetry in the low vowels between long front $\bar{\varnothing}$ and short back a, which could be resolved either by fronting a to $æ$, as in Anglo-Frisian, or by backing $\bar{x}$ to $\bar{a}$, as in the other languages (except Gothic, where $\bar{x}$ was raised to $\bar{e}$ at an early stage). If $\bar{\not}$ had been retracted to $\bar{a}$ in West Germanic already, the Anglo-Frisian fronting would be entirely unmotivated. Moreover, Caesar refers to the Swabians as Suébi, not ${ }^{*}{ }^{*} S u a \bar{a} \dot{i}$, which shows that we must reconstruct a front vowel for an early stage of Old High German. I therefore think that West Saxon $\bar{x}$ is an archaism and that the early retraction of $\bar{x}$ to $\bar{a}$ did not reach Anglo-Frisian.

Hans Nielsen lists three reasons for the assumption that $æ$ was first retracted to $\bar{a}$ and then fronted to $\mathfrak{x}$ in Anglo-Frisian (1981: 52f.). First of all, "the development of Gmc. ${ }^{*}-\bar{e} n,-\bar{e} m>$ OE/OFris. -ōn, -öm could hardly have taken place except by way of *ān, -ām". Secondly, 
"the borrowing of Latin strāta as strāzza in OHG and sträta in OS and as strèt(e) in Angl./Kt./OFris. and strāt in WS suggests that the forbears of OE/OFris. had an open vowel, which was subsequently fronted". And thirdly, "the expansion of $\bar{e}^{-1}$ to $\bar{a}$ was a direct consequence of the appearance of $\vec{e}^{2}$ in the long/tense subsystem of late Gmc. (NG/WG)". I think that none of these three arguments holds water.

First of all, it must be noted that the retraction of Proto-Germanic *$\bar{e}_{n}$ to ${ }^{*}-\bar{a} n$ is not only shared by Old Saxon and Old High German but also matched by a West Germanic delabialization of *-on and *-ōns to ${ }^{*}$-ăn, ${ }^{*}$-āns (cf. Kortlandt 1989: 103). This centralization before a tautosyllabic nasal is typologically similar to the development of nasal vowels in French, e.g. main, plein, bien, fin, un, brun, all with a nasalized central vowel in the modern language. It follows that no conclusions can be based on this new $* \bar{a}<* \ddot{z}, * \bar{o}$ before nasals, which evidently was an early West Germanic development.

Secondly, the borrowing of Latin strāta as West Germanic *stræita only shows that there was no $*_{\vec{a}}$ in the receiving language at the time and that $* \ddot{\varpi}$ was closer than $* \bar{o}$, which is unremarkable. Note that the final $-a$ was identified with the delabialized acc.sg. ending * $-0 n$. And thirdly, the rise of new $\bar{e}$ was probably recent because it represents earlier $* e a$ in Scandinavian and is preserved as $e a$ in early Old High German (cf. Kortlandt 1994). In fact, the diphthongization of $\bar{o}$ to $u_{0}$ in Old High German is best explained by the hypothesis that $e a>i a>$ ie was never monophthongized in the southern dialects of West Germanic. The spelling $e a$ is typical of Alemannic, as is the spelling $u a$ for $\bar{o}$, as opposed to $i e, u o$ in Franconian and ie beside $e a$ and $o a$ in Bavarian (cf. Rauch 1967: 37f., 25, 90).

Now we turn to the Anglo-Frisian palatalization. Fulk distinguishes between an early palatalization (stage 4) and a later phonemicization of palatals and assibilation (stage 10). This is an unfortunate split, not only because the late phonemicization of palatals effectively obliterates the explanatory value of the early palatalization, but also because it implies that the fronting of velar consonants was reversed by the restoration of a following $c e$ to $a$. When we look at other languages (Celtic, Slavic, Indic), we usually perceive a rising tide of palatalization, which first affects certain positions and then spreads to other environments (e.g., Greene 1974, Kortlandt 1979). The similarities and 
differences between the conditions for palatalization in English and Frisian rather suggest that we have to distinguish between an early Anglo-Frisian development and a later Old English innovation. Such a chronological split is strongly criticized by Hogg, who claims that "the various types of palatalization are prime candidates for simultaneous application" (1979: 108). On the contrary, it yields a much more natural chain of events than the alternating developments of fronting and backing listed above.

Thus, I would start from a vowel system with long front $* \dot{x}$ and short back $* a$, a general tendency to retract $\bar{\circledast}$ to $\bar{a}$, and a local tendency to front $a$ to $a$. If we want to avoid the assumption that fronted $a$ was again retracted to $a$, it follows that the Anglo-Frisian fronting of the short vowel was blocked by a following $l, r, h$ plus consonant and in open syllables by a back vowel in the following syllable. ${ }^{1}$ Since we do not find palatalization before *ai and *au in Frisian, it is natural to assume that *ai had been monophthongized to $\bar{a}$ before the AngloFrisian fronting of $a$ to $a$ and that $* a u$ had remained unchanged. The Anglo-Frisian palatalization then affected $k$ and $g$ before front vowels. After the "Saxon" migration to Britain, the fronting of $a$ to $a$ affected the remaining instances of $a$ in closed syllables, and also *au with $a$ before tautosyllabic $u$, in the dialect of the settlers. This "Saxon" second fronting was followed by breaking and second palatalization, e.g. in eald, ceeapian, OFr. ald 'old', kāpia 'buy'. In fact, the first stage of breaking can be identified with the "Saxon" fronting because the conditions were largely identical: it appears that the process of breaking began as incomplete fronting of $a$ before tautosyllabic $l, r, h$ and $u$ and subsequently affected $e$ and $i$. After the "Anglian" migration, these developments spread to the north, leaving traces only of the earlier situation.

In the meantime, Anglian shared the development of Frisian on the continent, in particular the raising of $æ \bar{e}$ to $\bar{e}$, which had been preceded by the Anglo-Frisian retraction of $\bar{x}$ to $\bar{a}$ before $w$ (cf. Fulk 1998: 141). The Kentish raising of $\check{z}$ to $\bar{e}$ was probably a local development, perhaps under the influence of a second invasion in Kent in the sixth century. After the "Anglian" migration, Frisian fronted $\bar{a}$ (from *ai) to

${ }^{1}$ Dr Dirk Boutkan points out to me that the same view was already put forward by Heuser (1903: 1). 
$\bar{\infty}$ unless it was followed by a back vowel in the following syllable and monophthongized $* a u$ to $\bar{a}$. The distinction between $\bar{e}<* \check{x}$ and $\bar{x}$ $<* a i$ is still preserved in modern dialects (cf. Campbell 1939: 101, fn.1). The Anglo-Frisian and second English palatalizations preceded umlaut (i-mutation) because the umlauted vowels did not palatalize $k$ and $g$ but phonemicized the opposition between palatals and velars, so that Old Frisian shows palatalization before $e<* \alpha$ and $\bar{e}<* \bar{x}$ but not before $e<* \ddot{a}$ or $\bar{\infty}<*$ ai, e.g. tsetel $<*$ katilaz 'kettle' and tziake < *kækōn 'jaw' versus kenna<*kannjan 'make known' and kēi, kāi < *kaijō 'key' (cf. already van Haeringen 1920: 31f.).

The main difference between the conventional wisdom that $a$ was fronted to $a$ and then retracted to $a$ before a back vowel in the following syllable and my view that these developments never took place concerns the interpretation of the form slean 'strike', which serves as the hackneyed example to demonstrate fronting and breaking in *slahan (e.g., Hogg 1979: 92, Fulk 1998: 150). It seems to me that insufficient attention has been paid to the paradigm of this word. If slēan were the phonetic reflex of *slahan as a result of fronting and breaking, it would be quite impossible to account for Northumbrian $\bar{e} a<$ *ahó 'water', where restoration of $a$ before the back vowel in the following syllable should have prevented breaking. In fact, Mercian ēo- and North. (Bede) -êu and the preservation of the contrast between the reflexes $\bar{e} o<{ }^{*}$ eho and $\bar{e} a<*^{*}$ eha in the Vespasian Psalter (cf. Campbell 1959: 103) show that we are not dealing with breaking but with contraction here. It appears that the loss of intervocalic *- $h$ - before rounded vowels was sufficiently early for the resulting diphthong *au to undergo the "Saxon" fronting to *au.

The verb slēan relates to faran as sēon<*sehan to beran. It has long been recognized that strong verbs of the sixth class have a strong tendency to restore the root vowel $a$ in West Saxon (e.g., Campbell 1959: 62). This is already an indication that the vocalism of slean cannot simply be attributed to generalization of breaking. We must rather assume that $a$ was restored in the imperative far and the subjunctive (optative) fare because this limited the front vowel to the 2 nd and $3 \mathrm{rd} \mathrm{sg}$. forms which had an umlauted vowel in other verbs and ask why the same development did not take place in the paradigm of * slahan. The parallelism between slēan and sēon suggests that their vocalism must be attributed to the early loss of $*$ - $h$ - before a rounded 
vowel and contraction in the $1 \mathrm{st} \mathrm{sg}$. and $3 \mathrm{rd} \mathrm{pl.} \mathrm{forms} *$ seu, ${ }^{*}$ slceu, *seop, *slæop, which eventually developed into sēo, slēa, sēop, slēap. When breaking yielded 2nd sg. *seohist, *slaeohist, 3rd sg. *seohip, * slæohip, imp. seoh, *slaeoh, subj. (opt.) *seohe, *slaohe, the stage was set for generalization of the broken vowel in the infinitives *seohan, *slaohan. The original distribution of front $a$ and back $a$ in the root is actually preserved in Old Frisian, where we find 3rd sg. present ind. sleith < ${ }^{*}$ slahip, subj. sle <*slahe, past participle slein, infinitive sla $<{ }^{*}$ slahan, gerund slande (cf. Boutkan 1996: 147). ${ }^{2}$

Thus, I regard the "Saxon" dialect of English as a variety of Ingvaeonic which generalized Anglo-Frisian fronting and palatalization and developed early breaking. In a similar vein, we may regard Mercian second fronting as a generalization of "Saxon" fronting after umlaut (cf. Fulk 1998: 149) under the influence of the "Anglian" raising of $\approx$ to $\tilde{e}$, and the same holds for Kentish raising of $\propto$ to $e$ after umlaut. While Old English breaking supplied short counterparts to the u-diphthongs, the Old Frisian breaking of $e$ yielded a short diphthong $* e u$ which was raised to $i u$ when original $* e u$ and $* i u$ developed into $i \bar{a}$ and $i \bar{u}$, respectively, e.g. siucht $<{ }^{*} \operatorname{seux} p<{ }^{*}$ sexp $<{ }^{*}$ sexip 'sees' (with restored root vowel, cf. Boutkan 1998: 82). ${ }^{3}$ All these developments seem to corroborate Krupatkin's view quoted above that changes in the short vowel system were adaptive to changes in the long vowel system.

\section{References}

Boutkan, Dirk. 1996. A concise grammar of the Old Frisian dialect of the First Riustring manuscript, Odense.

-. 1998. "On labial mutation and breaking in Old Frisian", in: $A B a ̈ G ~ 49,77-88$.

Campbell, Alistair. 1939. "Some Old Frisian sound-changes", in: Transactions of the Philological Society 1939, 78-107.

-. 1959. Old English Grammar, Oxford.

Fullk, Robert D. 1998. "The chronology of Anglo-Frisian sound changes", in: $A B \ddot{a} G$ $49,139-154$.

Greene, David. 1974. "The growth of palatalization in Irish", in: Transactions of the

2 I have now been convinced by Mottausch (1994: 137) that OE èode 'went', like Gothic iddja, must be derived from 3rd pl. *eijun, in spite of OE cæä < *kaijō 'key', and withdraw my earlier view (1991: 98).

3 The restoration of the root vowel $-e$ - in the strong verbs was probably an AngloFrisian development which was obliterated by "Saxon" umlaut (cf. Campbell 1959: 76, 300f., Fulk 1998: 149). 
Philological Society 1973, 127-136.

Haeringen, C.B. van, 1920. "Zur friesischen Lautgeschichte", in: PBB 44, 27-53.

Heuser, Wilhelm. 1903. Altfriesisches Lesebuch, Heidelberg

Hogg, Richard M. 1979. "Old English palatalization", in: Transactions of the Philological Society 1979, 89-113.

Kortlandt, Frederik. 1979. "The Old Irish absolute and conjunct endings and questions of relative chronology", in: Ériu 30, 35-53.

-. 1986. "The origin of the Old English dialects", in: Linguistics across historical and geographical boundaries I [Fs. Jacek Fisiak], Berlin, 437-442.

-. 1989. "The Germanic weak preterit", in: $A B a ̈ G ~ 28,101-109$.

—. 1991. "The Germanic seventh class of strong verbs", in: NOWELE 18, 97-100.

-. 1994. "On breaking", in: NOWELE 24, 15-19.

Krupatkin, Y.B. 1970. "From Germanic to English and Frisian", in: Us Wurk 19/3, 49-71.

Mottausch, Karl-Heinz. 1994. "Idg. ${ }^{*} \mathrm{~h}_{1}$ ei- 'gehen' im Germanischen", in: Historische Sprachforschung 107, 123-140.

Nielsen, Hans F. 1981. "Old Frisian and Old English dialects", in: Us Wurk 30/2, 49-66.

Rauch, Irmengard. 1967. The Old High German diphthongization, The Hague.. 